\title{
PENGGUNAAN BERBAGAI METODE MUTILASI UNTUK MEMBANDINGKAN LAMA WAKTU MOULTING KEPITING BAKAU MERAH (Scylla olivacea)
}

\section{COMPARISON OF THE DURATION OF RED MANGROVE CRAB (Scylla olivacea) MOULTING USING VARIOUS METHODS OF MUTILATION}

\author{
Ni Komang Santi Ariani ${ }^{1 *}$, Muhammad Junaidi ${ }^{1)}$, Alis Muklis ${ }^{2)}$ \\ Program Studi Budidaya Perairan, Universitas Mataram \\ Jl. Pendidikan No, 37 Mataram, NTB
}

\begin{abstract}
Abstrak
Penelitian ini bertujuan untuk mengetahui pengaruh pemotongan (mutilasi) organ gerak terhadap periode moulting dan mengetahui waktu tercepat pencapaian moulting pada kepiting bakau merah dengan berbagai metode mutilasi. Penelitian ini dilakukan pada bulan Agustus-Oktober 2017 yang bertempat di tambak Dusun Puyahan, Desa Lembar Selatan, Kabupaten Lombok Barat. Penelitian ini menggunakan metode eksperimental dengan Rancangan Acak Lengkap dengan lima perlakuan yakni tanpa perlakuan mutilasi (A), mutilasi sepasang capit (B), mutilasi seluruh kaki jalan (C), mutilasi sepasang kaki renang (D), dan mutilasi seluruh organ gerak (E). Masing-masing perlakuan diulang sebanyak 3 kali sehingga diperoleh 15 unit percobaan. Hasil penelitian menunjukkan bahwa adanya pengaruh yang nyata antara mutilasi organ gerak kepiting bakau terhadap periode moulting. Kepiting bakau merah yang diberikan perlakuan mutilasi seluruh organ gerak menunjukkan moulting tercepat dibandingkan perlakuan yang lainnya. Waktu yang dibutuhkan kepiting bakau merah mencapai moulting dengan perlakuan mutilasi seluruh organ gerak yaitu rata-rata 32 hari. Dilihat dari hasil pengukuran bobot mutlak dan bobot relatif tubuh kepiting bakau menunjukkan hasil yang tidak berbeda nyata. Kualitas air selama penelitian yaitu salinitas berkisar antara 28 - $36 \mathrm{ppt}$, oksigen terlarut yaitu 4,5-8,4 mg/L, pH berkisar 8-9, suhu berkisar $28-33^{\circ} \mathrm{C}$ dan amoniak $0,5 \mathrm{mg} / \mathrm{L}$.
\end{abstract}

Kata kunci : kepiting bakau merah, mutilasi, moulting, waktu, bobot tubuh

\begin{abstract}
Research are aimed to know the effect of cutting (mutilating) motion organ on moultingperiod and to know the fastest time of moultingattainment on red mangrove crabs with various methods of mutilation. The research was conducted in August to October 2017, located in Puyahan fishpond, South Lembar Village, West Lombok. The study used an experimental method with a Completely Randomized Design with five treatmentswhich were without mutilation treatment (A), mutilation of a pair of claws (B), mutilation of the entire foot $(C)$, mutilation of a pair of swimming legs (D), and mutilation of the whole organ of motion (E). Each treatment was repeated 3 times to obtain 15 experimental units. The results show that there was a significant effect of organ mutiliation of mangrove crab on moulting period. Red mangrove crabs which were given mutilation treatment for all organs of motion showed the fastest moulting compared to other treatments. The time needed to moulting by the treatment of mutilation of all the motion organs was 32 days in averages. There were no differences of weigh gain and relative growth rate between all the treatments. Water quality during the study was salinity ranging from 28-36 ppt, dissolved oxygen was 4.5-8.4 mg/L, pH 8-9, temperature $28-33^{\circ} \mathrm{C}$ and ammonia $0.5 \mathrm{mg} / \mathrm{L}$.
\end{abstract}

Keywords: red mangrove crab, mutilation, moulting, time, weight.

\section{Pendahuluan}

Kepiting bakau merupakan salah satu komodit perikanan yang bernilai ekonomi *email korespondensi: arianishanti.as@gmail.com tinggi dengan harga di pasar dalam negeri berkisar antara Rp 30.000,- sampai Rp 40.000,per kilogram (Bank Indonesia, 2011). Khusus bagi kepiting bakau yang baru saja mengalami 
gantikulit (moulting) dengan kondisi karapas yang masih lunak (kepiting soka) harganya relative lebih tinggi, berkisar antara $\mathrm{Rp}$ 40.000,- sampai Rp 56.000,-per kilogram yang berisi $10-12$ ekor (Bank Indonesia, 2011). Karena kondisi cangkangnya yang masih lunak maka keseluruhan bagian tubuh kepiting soka dapat dikonsumsi.

Tingginya peminat terhadap kepiting soka mendorong para pembudidaya untuk memproduksi lebih banyak kepiting soka. Salah satu kendala yang dialami dalam kegiatan produksi kepiting soka penggunaan metode mutilasi organ tubuh seperti kaki jalandan kaki renang. Banyak pihakyang berpendapat bahwa penggunaan metode mutilasi ini merupakan salah satu tindakan yang kurang berkenan dihati para pencinta binatang.

Berbagai metode lain untuk mempercepat moulting kepiting bakau sudah digunakan seperti manipulasi lingkungan, penambahan hormon dan pemberian ekstrak tumbuhan. Namun demikian metode ini dinilai hanya cocok diterapkan pada produksi kepiting soka skala laboratorium atau skala kecil, sedangkan untuk produksi skala missal lebih cocok menggunakan metode mutilasi (Harianto, 2015).

Metode mutilasi biasanya melakukan pemotongan pada bagian organ kaki jalan, capit dan kaki renang. Teknik ini merupakan upaya untuk meningkatkan produk kepiting cangkang lunak (soka) karena dapat merangsang keluarnya hormon exdecis untuk memicu terjadinya pergantian kulit dengan cepat. Hormon yang menghambat kepiting bakau moulting terletak pada organ gerak kepiting bakau (Samidjan dan Rachmawati, 2015).

Berdasarkan paparan di atas, maka dilakukan penelitian untuk mengkaji lama waktu yang dibutuhkan kepiting bakau merah agar mencapai moulting menggunakan metode mutilasi pada bagian anggota gerak kepiting bakau.penelitian ini diharapkan dapat memberi informasi dasar mengenai perbandingan berbagai metode mutilasi pada organ gerak kepiting bakau merah (Scylla olivacea) untuk memicu percepatan moulting sehingga dapat diaplikasikan untuk produksi kepiting soka oleh pembudidaya.

\section{Metode Penelitian}

Penelititian telah dilaksanakan pada bulan Agustusn sampai Oktober 2017 yang bertempat di tambak Dusun Puyahan, Desa Lembar Selatan, Kabupaten Lombok Barat. Alat yang digunakan pada penelitian ini yaitu crab box, bambu, timbangan, gunting, kamera, lilin, korek api, spidol permanen, ember, gelas ukur, keranjang plastik ukuran $100 \times 50 \mathrm{~cm}$, keranjang palstik ukuran $20 \times 20 \mathrm{~cm}$, sepit, waring, tali nilon, patok kayu, kabel tis, kulkas, mangkuk plastik, termometer air, $\mathrm{pH}$ meter, refraktometer, DO meter, tes kit amoniak, dan alat tulis. Bahan yang digunakan pada penelitian ini yaitu kepiting bakau merah (Scylla olivacea) dengan berat $100 \pm 10$ g/ekor, air tawar, air payau, pakan kepiting berupa ikan rucah jenis ikan tembang, alkohol $70 \%$, formalin $25 \mathrm{~g} /$ liter

Metode yang digunakan adalah metode eksperimental dengan Rancangan Acak Lengkap (RAL) yang terdiri atas 5 perlakuan antara lain tanpa mutilasi organ gerak (A), mutilasi pada sepasang capit kepiting (B), Mutilasi pada seluruh kaki jalan (C), mutilasi pada sepasang kaki renang (D), dan mutilasi pada seluruh organ gerak (E) dengan ulangan sebanyak 3 kali sehingga diperoleh 15 unit percobaan.

Parameter yang diuji secara statistik adalah Waktu yang dibutuhkan oleh kepiting bakau mencapai moulting diamati dari hari pertama diberikan perlakuan dan penebaran sampai dengan terlepasnya kepiting dari karapas lama dengan tumbuhnya organ gerak yang lengkap pada kepiting bakau merah (Habibi dkk., 2013). Rumus untuk Pertumbuhan mutlak bobot tubuh, W $=\mathrm{Wt}-$ Wo (Samidjan dan Rachmawati, 2015); Laju pertumbuhan relatif bobot tubuh, Wrelatif $=((\mathrm{Wt}-\mathrm{W} 0): \mathrm{W} 0) \times 100 \%$ (Aslamyah dan Fujaya, 2010); dimana, $\mathrm{W}=$ Pertambahan bobot mutlak (g); Wt = Bobot hewan uji pada akhir penelitian $(\mathrm{g})$; Wo $=$ Bobot hewan uji pada awal penelitian $(\mathrm{g})$; $\mathrm{W}$ relatif = Pertumbuhan realtif; $\mathrm{Wt}=$ Bobot hewan uji pada akhir penelitian $(\mathrm{g})$; Wo = Bobot hewan uji pada awal penelitian (g). 


\section{Hasil}

\section{Periode Mencapai Moulting}

Moulting tercepat secara berurutan dicapai oleh perlakuan mutilasi seluruh organ gerak yaitu 32 hari, perlakuan mutilasi sepasang capit yaitu 43 hari, perlakuan mutilasi seluruh kaki jalan yaitu 46 hari, perlakuan mutilasi sepasang kaki renang yaitu
50 hari dan tanpa perlakuan mutilasi yaitu 54 hari (Gambar 1).

Dilihat dari hasil sidik ragam pada taraf nyata $5 \%$ bahwa nilai $\mathrm{F}$ hitung $(8,356)$ lebih besar dari $\mathrm{F}$ tabel $(3,478)$ sehingga kepiting bakau merah yang diberikan perlakuan mutilasi pada seluruh organ gerak menunjukkan hasil yang signifikan terhadap periode moulting.

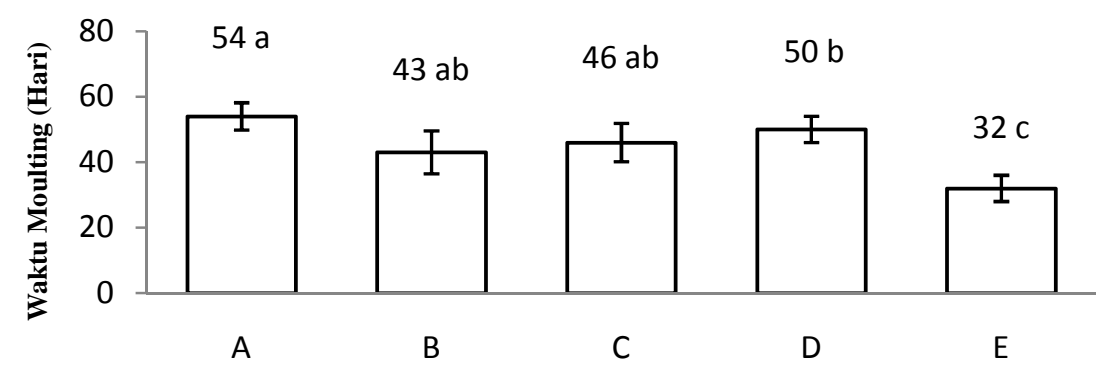

Perlakuan

Gambar 1. Waktu yang dibutuhkan kepiting bakau merah (Scylla olivacea)untuk mencapai moulting yang diberikan perlakuan A (tanpa pemotongan organ gerak), B (Pemotongan sepasang capit), C (pemotongan semua kaki jalan), D (pemotongan sepasang kaki renang), dan E (pemotongan seluruh organ gerak). Garis tegak lurus merupakan standar deviasi dan notasi yang berbeda menunjukkan perbedaan antar perlakuan.

\section{Pertumbuhan Bobot Tubuh}

Hasil pengamatan bobot tubuh kepiting bakau merah yang dilakukan setiap minggu menunjukkan pola pertumbuhan linier yang terus meningkat pada perlakuan kontrol dan mutilasi seluruh organ gerak hingga pada akhir penelitian. Namun demikian, hal yang berbeda pada perlakuan mutilasi sepasang capit, mutilasi seluruh kaki jalan dan mutilasi sepasang kaki renang yang mengalami penurunan pada pada akhir penelitian (Gambar 2).

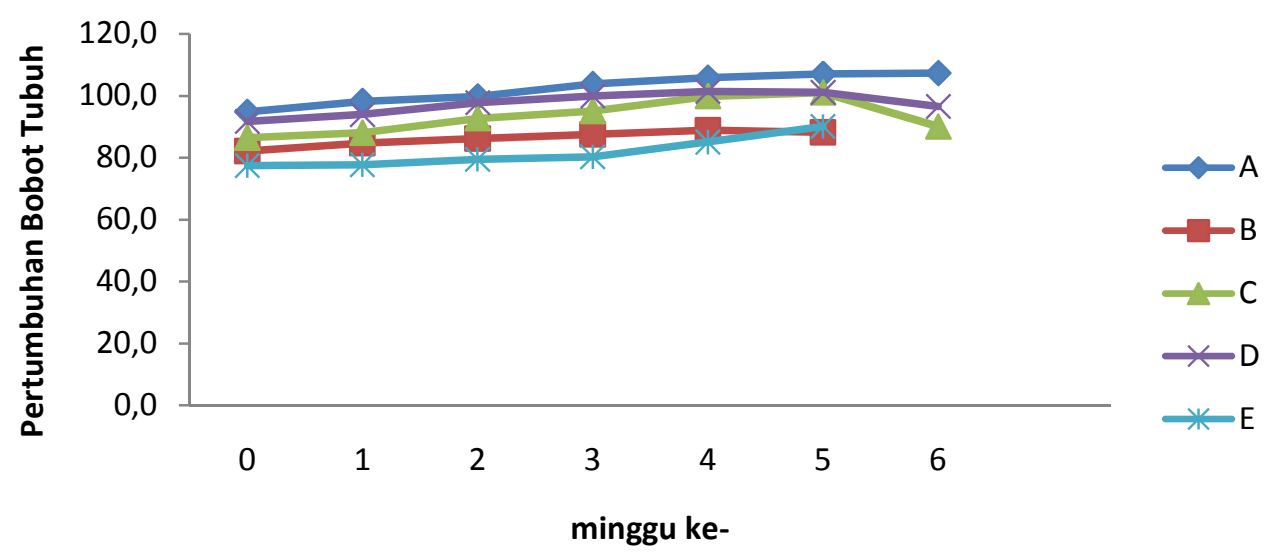

Gambar 2.Pertambahan bobot tubuh kepiting bakau merah (Scylla olivacea)selama 60 hari hingga moulting yang diberikan perlakuan A (tanpa pemotongan organ gerak), B (Pemotongan sepasang capit), $\mathrm{C}$ (pemotongan semua kaki jalan), D (pemotongan sepasang kaki renang), dan $\mathrm{E}$ (pemotongan seluruh organ gerak). 


\section{Pertumbuhan mutlak bobot tubuh}

Hasil analisis pertumbuhan mutlak bobot tubuh hewan uji (Gambar 3) menunjukkan petumbuhan bobot mutlak tertinggi dicapai oleh perlakuan kontrol dan perlakuan mutilasi seluruh kaki jalan dengan nilai yang sama yaitu $13,25 \mathrm{~g}$ yang masingmasing diperoleh dalam waktu 54 hari dan 46 hari. Pertumbuhan mutlak bobot tubuh terendah diperoleh pada perlakuan mutilasi seluruh organ gerak sebesar 5,92 g. Meskipun nilai pertumbuhan mutlak bobot tubuh berbeda, namun dilihat dari hasil analisis sidik ragam pada taraf nyata 5\%menunjukkan bahwa nilai $\mathrm{F}$ hitung $(0,992)$ lebih kecil dari nilai $F$ tabel $(3,478)$ yang berarti bahwa pemberian perlakuan mutilasi pada organ gerak tidak memberikan pengaruh yang signifikan terhadap pertumbuhan mutlak.

\section{Pertumbuhan relatif bobot tubuh}

Hasil analisis pertumbuhan relatif bobot tubuh kepiting bakau merah (Gambar 4), pertumbuhan relatif bobot tubuh kepiting bakau merah tertinggi dicapai oleh perlakuan mutilasi seluruh kaki jalan sebesar 15,32\% dari bobot awal, sedangkan pertumbuhan relatif bobot tubuh terendah dicapai oleh perlakuan mutilasi seluruh organ gerak sebesar 5,92\% dari bobot awal. Dilihat dari hasil analisis sidik ragam pada taraf nyata $5 \%$ menunjukkan bahwa nilai $\mathrm{F}$ hitung $(1,029)$ lebih kecil dari nilai $F$ tabel $(3,478)$ yang berarti bahwa pemberian perlakuan mutilasi pada organ gerak kepiting bakau merah tidak memberikan pengaruh yang signifikan terhadap pertumbuhan relatif bobot tubuh walaupun nilai dari hasil analisis pertumbuhan relatif bobot tubuh kepiting bakau merah menunjukkan perbedaan.

\section{Kualitas Air}

Hasil yang diperoleh dari pengukuran kualitas air yaitu didapatkan salinitas berkisar antara 28-36 ppt, oksigen terlarut berkisar antara 4,5-8,4 $\mathrm{mg} / \mathrm{L}, \mathrm{pH}$ berkisar antara 8-9, suhu berkisar antara $28-33^{\circ} \mathrm{C}$, dan amoniak dengan nilai $0,5 \mathrm{mg} / \mathrm{L}$.

\section{Pembahasan}

Hormon Ekdisteroid adalah hormon yang terdapat pada Arthropoda dan Crustaceae yang keberadaannya untuk merangsang terjadinya moulting (Bakrim, 2008; Nurmadina dkk., 2014). Kepiting bakau merah yang mencapai moulting tercepat yaitu pada perlakuan mutilasi seluruh organ gerak dengan lama pencapaian moulting rata-rata 32 hari. Cepatnya kepiting bakau merah pada perlakuan pemotongan seluruh anggota gerak yang dikarenakan berkurangnya bahkan hilangnya hormon penghambat moulting yaitu Molt Inhibiting Hormone (MIH) yang dihasilkan oleh organ X. Hal ini sesuai dengan pernyataan Habibi dkk. (2013) akibat mutilasi pada seluruh anggota gerak tubuh menyebabkan keberadaan hormon MIH pada kaki berkurang bahkan hilang yang dikarenakan organ $\mathrm{Y}$ terespon dan menghasilkan hormon Ekdisteroid untuk merangsang moulting.

Perlakuan mutilasi sepasang capit, perlakuan mutilasi seluruh kaki jalan dan mutilasi sepasang kaki renang mencapai moultingsecara berurutan yaiturata-rata 43 hari, 46 hari dan 50 hari. Perlakuan tersebut relatif lebih lama dibandingkan dengan perlakuan mutilasi seluruh anggota gerak. Diduga hal ini disebabkan oleh MIH yang masih diproduksi oleh organ $\mathrm{X}$, sedangkan organ $\mathrm{Y}$ yang menghasilkan hormon Ekdisteroid belum bekerja dengan maksimal. Kepiting bakau merah tanpa perlakuan mutilasi menunjukkan pencapaian waktu moulting terlama rata-rata 54 hari. Hasil tersebut menunjukkan bahwa organ $\mathrm{X}$ masih memproduksi MIH dan organ Y lambat dalam memproduksi hormon Ekdisteroid. Habibi dkk. (2013) menyatakan bahwa, MIH yang dihasilkan oleh organ $\mathrm{X}$ dan disimpan dalam sinus gland kemudian didistribusikan ke dalam sirkulasi darah yang relatif lama, jika konsentrasi MIH dalam hemolimph sudah menurun maka organ $\mathrm{Y}$ terangsang untuk menghasilkan hormon Ekdisteroid sampai batas maksimal sehingga kepiting mengalami moulting dalam waktu relatif lama.

Kepiting bakau merah yang telah dimutilasi akan mengalami regenerasi anggota tubuh. Organ gerak yang dimutilasi akan kembali dalam bentuk semula setelah mengalami moulting. Jika kepiting bakau merah yang mengalami kehilangan anggota tubuhnya maka hormon ekdisteroid bekerja semakin aktif untuk memicu moulting. Hal ini sesuai dengan pernyataanSamidjan dan Rachmawati (2015), bentuk tubuh kepiting yang berubah dipengaruhi oleh regenerasi anggota tubuh yang putus dan energi untuk 
pertumbuhan akan difokuskan pada pembentukan jaringan baru untuk anggota tubuh yang putus.

Pertumbuhan yang dialami oleh kepiting bakau merah pada semua perlakuan umumnya mengalami peningkatan bobot tubuh per minggu sejak awal pemeliharaan, namun pada akhir penelitian mengalami penurunan pada satu minggu sebelum akhir penelitian. Penurunan bobot tubuh ini diduga karena kepiting bakau merah yang dipelihara mengalami moulting pada hari yang berbedabeda sehingga berpengaruh pada hasil akhir analisis bobot tubuh kepiting bakau merah.

Pada perlakuan kontrol dan mutilasi seluruh kaki jalan menunjukan nilai rata-rata tertinggi karena kondisi capit kepiting tidak dimutilasi sehingga kepiting masih bisa memegang pakan yang diberikan. Menurut Aditya dkk. (2012), kepiting bakau memiliki kebiasaan mencapit makanannya sebelum dimasukkan ke dalam mulut dan mempengaruhi jumlah pakan yang dikonsumsi serta keluaran energi untuk melakukan aktivitas yang di mana hal tersebut dapat mempengaruhi pertumbuhannya. Hasil ratarata terendah yaitu pada perlakuan mutilasi seluruh anggota gerak. Dilihat saat di lapangan, kepiting bakau yang capitnya telah dimutilasi mengalami kesulitan saat mengkonsumsi pakan yang diberikan. Rendahnya rerata bobot mutlak pada perlakuan mutilasi seluruh organ gerak dan perlakuan mutilasi sepasang capit diduga karena kepiting bakau yang memiliki kebiasaan mencapit pakan merasa sulit untuk makan sehingga berpengaruh pada jumlah pakan yang dikonsumsi.

Meskipun menunjukkan hasil yang tidak signifikan, namun pada perlakuan mutilasi seluruh kaki jalan menunjukkan nilai yang lebih tinggi dibandingkan dengan perlakuan yang lainnya. Hal ini diduga karena kepiting bakau merah yang diberi perlakuan mutilasi seluruh kaki jalan masih bisa mencapit pakan dan mengkonsumsi pakan sebagai energi untuk pertumbuhan. Menurut Kasry (2010);Sadinar dkk. (2013) menyatakan bahwa kepiting bakau memanfaatkan lemak, protein dan karbohidrat sebagai penyuplai energi untuk perkembangan embrio, namun sebagian besar energi tersebut digunakan untuk pembentukan cangkang. Pakan adalah salah satu faktor biologis sangat penting bagi kepiting dan pakan memberikan pengaruh yang sangat besar terhadap pertumbuhan dan kelangsungan hidup kepiting (Suwarsito, 2004 dalam Septian dkk., 2013). Rendahnya rerata bobot relatif kepiting bakau merah pada perlakuan mutilasi seluruh organ gerak diduga karena kesulitan saat kepiting bakau merah mengkonsumsi pakan yang dikarenakan capit kepiting bakau merah telah dimutilasi sehingga rendahnya asupan nutrisi yang masuk ke dalam tubuh kepiting bakau merah.

Meskipun sudah dilakukan homogenitas ukuran dan bobot tubuh kepiting bakau sebelum memulai penelitian namun pada akhir penelitian diperoleh hasil sidik ragam yang tidak berbeda nyata pada pertumbuhan mutlak dan pertumbuhan relatif bobot tubuh kepiting bakau merah. Laju pertumbuhan dipengaruhi oleh dua faktor yaitu faktor internal yang meliputi keturunan, umur, jenis kelamin, reproduksi, ketahanan terhadap penyakit, dan kemampuan untuk memanfaatka pakan, sedangkan faktor eksternal meliputi kualitas air, kepadatan dan pakan (Djunaedi, 2016). Diduga hasil akhir yang diperoleh disebabkan karena faktor internal seperti keturunan, umur dan kemampuan untuk memanfaatkan pakan yang dimana disebutkan tadi cukup sulit untuk disamakan karena kepiting bakau merah yang digunakan sebagai hewan uji pada penelitian ini diperoleh dari nelayan yang menangkap kepiting bakau merah dari alam yang dimana hewan uji tersebut berasal dari induk yang berbeda-beda.

Selama penelitian didapatkan hasil dari pengukuran salinitas yaitu kisaran 28 - 36 ppt. Menurut Habibi dkk. (2013), salinitas optimal untuk memelihara kepiting bakau berkisar 10 32 ppt. Lokasi penelitian yang dilakukan di tambak memberikan pengaruh terhadap perubahan salinitas yang dikarenakan oleh adanya aliran sungai dan pasang surutnya air laut. Senada dengan pernyataan Sagala dkk.(2013), perubahan salinitas dapat disebabkan oleh beberapa faktor yaitu pola sirkulasi air, penguapan, curah hujan dan aliran sungai. Kisaran oksigen terlaruh yang diperoleh selama penelitian yaitu 4,5 - 8,4 $\mathrm{mg} / \mathrm{L}$. Kondisi tersebut masih dalam kisaran optimum yaitu $3,7 \quad-\quad 8,9 \mathrm{mg} / \mathrm{L}$ untuk pemeliharaan kepiting bakau merah (Herlinah dkk., 2010). Nilai pH selama penelitian yaitu kisaran 8 - 9 dan angka tersebut masih dalam kiasaran optimum untuk memelihara kepiting bakau yaitu $7-9$ (Samidjan dan Rachmawati,2015). Nilai suhu yang dipeloreh 
selama penelitian yaitu $28-33^{\circ} \mathrm{C}$ dan amoniak yaitu $0,5 \mathrm{mg} / \mathrm{L}$, nilai tersebut masih dalam kisaran optimum untuk memelihara kepiting bakau yaitu suhu optimum $23-32{ }^{\circ} \mathrm{C}$ (Soim, 1999 dalam Septian dkk.(2013) dan amoniak kurang dari 1 (Kordi, 2000 dalam Samidjan dan Rachmawati, 2015). Dilihat dari keseluruhan, kualitas air pada tambak tempat pemeliharaan kepiting bakau termasuk layak digunakan untuk pemeliharaan kepiting bakau merah karena selama selama pemeliharaan, kepiting berhasil hidup dan mencapai fase moulting.

\section{Kesimpulan}

Mutilasi organ gerak memberikan pengaruh yang nyata terhadap periode moulting kepiting bakau merah, namun tidak memberikan pengaruh nyata terhadap pertumbuhan bobot tubuh pada kepiting bakau merah. Kepiting bakau merah yang mencapai moulting tercepat yaitu pada perlakuan mutilasi seluruh organ gerak mencapai ratarata 32 hari.

\section{Ucapan Terima Kasih}

Penulis menyampaikan terima kasih kepada bapak Muhadi dan pemuda warga kampung Ujat Ngering yang telah ikut membantu dalam perakitan wadah dan persiapan tambak yang dilakukan dalam penelitian ini.

\section{Daftar Pustaka}

Aditya, B.P., Sunaryo, dan D. Ali. (2012). Pemberian Pelet dengan Ukuran Berbeda Terhadap Pertumbuhan Kepiting Bakau (Scylla serrata Forsskal, 1775). Journal of Marine Research. Vol. 1 (1): 146-152.

Bakrim, A., (2008). Ecdysteroid in Spinach (Spinacia oleracea L): Biosynthesis, Transport and Regulation of Levels. Online Abstract. PlantPhysiology and Biochemistry. Vol 46 (10): 844-854.

Bank Indonesia. (2011). Budidaya Kepiting Soka, Pola Pembiayaan Usaha Kecil. Jakarta Pusat.

Djunaedi, A. (2016). Pertumbuhan dan Prosentase Molting pada Kepiting Bakau (Scylla serrata Forsskal, 1775) dengan Pemberiani Stimulasi Moulting Berbeda.
Jurnal Kelautan Tropis. Vol. 19 (1): 2936

Habibi, M.W., H. Dyah., dan K. Nur. (2013). Perbedaan Lama Waktu Moulting Kepiting Bakau (Scylla serrata) Jantan dengan Mutilasi dan Ablasi.. LenteraBio. Vol.2 (3): 265-270.

Harianto, E. (2015). Kinerja Produksi Kepiting Bakau Scylla serrata Cangkang Lunak pada Metode Pemotongan Capit dan Kaki Jalan, Popey, dan Alami. Jurnal Ilmiah Universitas Batanghari Jambi. Vol. 15 (1): $15-21$.

Herlinah., Sulaeman., dan T. Andi. (2010). Pembesaran Kepiting Bakau (Scylla serrata) di Tambak dengan Pemberian Pakan Berbeda. Prosiding Forum Inovasi Teknologi Akuakultur: 169-174.

Kasry, A. (1999). Budidaya Kepiting Bakau dan Biologi Ringkas. Penerbit Bharata. Jakarta 93 hal.

Nurmadina,. Mulyadi,. dan M.T. Usman. (2014). Producing Speed Moulting in Mud Crab (Scylla serrata) With Soft Shell Ablation And Mutilation Method. Fakultas Perikanan dan Ilmu Kelautan. Universitas Riau.

Sadinar, B., S. Istiyanto., dan R. Diana. (2013). Pengaruh Perbedaan Dosis Pakan Keong Mas dan Ikan Rucah pada Kepiting Bakau (Scylla paramamosain) Terhadap Pertumbuhan dan Kelulushidupan dengan Sistem Battery di Tambak Tugu, Semarang. Jurnal of Aquaculture Management and Technologi. Vol. 2 (4): 84-93.

Sagala, L.S.S., I. Muhammad., dan N.I. Mohammad. (2013). Perbandingan Pertumbuhan Kepiting Bakau (Scylla serrata) Jantan dan Betina Pada Metode Kurungan Dasar. Jurnal Mina Laut Indonesia. Vol. 3 (12): 46-54.

Samidjan, I., dan D. Rachmawati. (2015). Rekayasa Budidaya Kepiting Bakau Melalui Pemotongan Kaki Jalan Dalam Upaya Penigkatan Produksi Kepiting Soka (Soft Shell). Universitas Diponegoro: 103-118.

Septian, R., I. Samidjan., dan D. Rachmawati. (2013). Pengaruh pemberian Kombinasi Pakan Ikan Rucah dan Buatan yang Diperkaya Vitamin E Terhadap Pertumbuhan dan Kelulushidupan Kepiting Soka (Scylla paramamosain). 
Jurnal Perikanan (2018) Volume 8. No. 1.: 40-46

Jurnal of Aquaculture Management and Technologi. Vol. 2 (1): 13-24. 